WSRC-TR-97-0325, Rev. 0

\title{
Decomposition of Triphenylborane with Enhanced Comprehensive Catalyst Under Aerated and Inert Conditions
}

by

W. R. Wilmarth

Westinghouse Savannah River Company

Savannah River Site

Aiken, South Carolina 29808

C. L. Crawtord

R. A. Peterson

T. L. White

\section{MASTER}

DOE Contract No. DE-AC09-89SR18035

This paper was prepared in connection with work done under the above contract number with the U.S. Department of Energy. By acceptance of this paper, the publisher and/or recipient acknowledges the U.S. Government's right to retain a nonexclusive, royalty-free license in and to any copyright covering this paper, along with the right to reproduce and to authorize others to reproduce all or part of the copyrighted paper. 


\section{DISCLAIMER}

Portions of this document may be illegible electronic image products. Images are produced from the best available original document. 
WSRC-TR-97-0325, Rev. 0

Decomposition of Triphenylborane with Enhanced Comprehensive Catalyst under Aerated and Inert Conditions $(U)$

W. R. Wilmarth

C. L. Crawford

R. A. Peterson

T. L. White

Publication Date: September 30, 1997

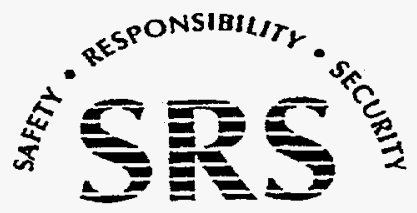




\section{DISCLAIMER}

This report was prepared as an account of work sponsored by an agency of the United States Government. Neither the United States Government nor any agency thereof, nor any of their employees, makes any warranty, express or implied, or assumes any legal liability or responsibility for the accuracy, completeness, or usefulness of any information, apparatus, product, or process disclosed, or represents that its use would not infringe privately owned rights. Reference herein to any specific commercial product, process, or service by trade name, trademark, manufacturer, or otherwise does not necessarily constitute or imply its endorsement, recommendation, or favoring by the United States Government or any agency thereof. The views and opinions of authors expressed herein do not necessarily state or reflect those of the United States Government or any agency thereof.

This report has been reproduced directly from the best available copy.

Available to DOE and DOE contractors from the Office of Scientific and Technical Information, P.O. Box 62, Oak Ridge, TN 37831; prices available from (615) 576-8401.

Available to the public from the National Technical Information Service, U.S. Department of Commerce, 5285 Port Royal Road, Springfield, VA 22161. 


\title{
Enhanced Catalysis Composition Decomposition of Triphenylborane under Aerated and Inert Conditions (U)
}

\author{
W. R. Wilmarth, C. L. Crawford and R. A. Peterson \\ Waste Processing Technology Section \\ T. L. White \\ Analytical Development Section \\ Savannah River Technology Center \\ Westinghouse Savannah River Company
}

\begin{abstract}
This work investigated the decomposition of triphenylborane in a statistically-designed set of tests to determine the effects of four process variables: temperature, hydroxide concentration, catalyst concentration, and atmosphere. Analysis of these tests provide the following conclusions.
\end{abstract}

- The presence of tetraphenylborate solids facilitate a $10 \mathrm{X}$ increase in the rate of decomposition of triphenylborane.

- The presence of oxygen slows the decomposition of triphenylborane.

- The activation energy of the decomposition reaction in the presence of oxygen $(59.88 \pm 27.73$ $\mathrm{kJ} / \mathrm{mol})$ is statistically lower than inerted systems $(99.11 \pm 20.14 \mathrm{~kJ} / \mathrm{mol})$.

- Rate constants derived from the nitrogen inerted tests encompass the rate constants from previous tests.with slurries. These rate constants agree reasonably with similar values obtained from Tank $48 \mathrm{H}$ operations at ambient temperatures.

- For tests conducted in air, the decomposition reaction rate constant correlated with the catalyst concentration. In tests inerted by nitrogen, the same correlation did not hold.

\section{Introduction}

The chemistry of the phenylborates in aqueous, alkaline media received intense study as a result of the benzene releases from the In-Tank precipitation (ITP) facility. ${ }^{1-3}$ Current interest focuses on the tetraphenylborate decomposition intermediates including triphenylborane.

Triphenylborane, quite soluble under these conditions, ${ }^{4}$ reacts rapidly in the presence of catalytic metals. High-Level Waste Engineering requested studies of the decomposition of triphenylborane under simulated waste tank chemistries to ascertain rate-limiting kinetic data. 
Crawford and Peterson ${ }^{6}$ originally studied the catalyzed decomposition of the tetraphenylborate intermediates. These studies used copper as the catalyst and provided rate expressions that suggested lower decomposition rates for $3 \mathrm{~PB}$ than observed in Tank $48 \mathrm{H}$. Hyder studied the role of oxygen in the decomposition of the intermediates. Hyder's data for 3PB decomposition indicated a possible acceleration of the rate under inert conditions. Therefore, Crawford et al. studied the decomposition of triphenylborane using copper as the catalyst under inerted conditions and observed a lower rate of decomposition than predicted based on Hyder's data. The highest observed decomposition rate observed for triphenylborane comes from a set of sodium tetraphenylborate decomposition experiments using the Enhanced Comprehensive Catalyst (ECC) in the presence of sodium and potassium tetraphenylborate solids.

This study used a statistically-designed set of experiments to determine the decomposition rates for triphenylborane as a function of ECC concentration, atmosphere (air or nitrogen), temperature, and hydroxide ion concentration. This data will aid in process modeling of the benzene generation in Tanks $48 \mathrm{H}, 49 \mathrm{H}$ and $50 \mathrm{H}$.

\section{Experimental}

Researchers studied the decomposition of triphenylborane in sodium hydroxide solutions containing the Enhanced Comprehensive Catalyst (ECC) utilizing a statistical design with the following variables listed in Table 1 and Table 2.

- Table 1. Triphenylborane Decomposition Test Parameters

\begin{tabular}{ll}
\hline Parameter & $\underline{\text { Levels }}$ \\
Temperature & 25,40 and $55^{\circ} \mathrm{C}$ \\
Hydroxide Concentration & $0.5,1.5$, and $2.5 \mathrm{M}$ \\
ECC Concentration & $0.5 \mathrm{x}, 1.0 \mathrm{x}$, and $2.0 \mathrm{x}$ \\
Atmosphere & Air and Nitrogen \\
\hline
\end{tabular}

Personnel dissolved reagent-grade sodium hydroxide in distilled, deionized water to provide a $0.5 \mathrm{M}, 1.5 \mathrm{M}$ and $2.5 \mathrm{M}$ stock solutions. Tests added triphenylborane as the nominally $9 \mathrm{wt} \%$ sodium hydroxide adduct obtained from Aldrich Chemical Company.

The tests utilized glass, $160-\mathrm{mL}$ serum vials as the reaction vessel. The vessel contained nominally $75 \mathrm{~mL}$ of the sodium hydroxide stock solution along with 3 grams of reagent-grade sodium tetraphenylborate and solid components of the Enhanced Comprehensive Catalyst. The amount of sodium tetraphenylborate provided a $4 \mathrm{wt} \%$ potassium tetraphenylborate slurry. The 
vessels requiring inert conditioning were sealed and sparged with house-supplied nitrogen for a minimum of 30 minutes. Concurrently, researchers prepared a $1.85 \mathrm{M}$ potassium hydroxide solution by sparging the solution with nitrogen.

Researchers added $\mathrm{KOH}$ to each reaction vessel and stirred for approximately $2-3$ days to allow for potassium precipitation. They then added liquid ECC components to complete the catalyst compositions. The catalyst included the full suite of species including palladium and diphenylmercury as listed in Table 3 . Vessels sealed in air according to the matrix were prepared in an identical manner.

Triphenylborane was added following a negative qualitative test performed for the presence of tetraphenylborate ion. A small aliquot of a saturated potassium chloride solution was added to the solution as the qualitative test for tetraphenylborate ion. Personnel removed samples after 30 minutes of stirring at room temperature to provide for the initial intermediate concentrations.

During this experiment, researchers filtered aliquots $(\sim 4 \mathrm{~mL})$ of the slurry using a 0.45 micron syringe filter to remove potassium tetraphenylborate solids. Analysis of filtered samples used High Performance Liquid Chromatography (HPLC) with routine quality assurance protocols. ${ }^{10}$

Table 2. Statistically Designed Matrix for Triphenylborane ECC-Catalyzed Decomposition

\begin{tabular}{ccccll}
\hline Row & Pattern & Temp & {$[\mathrm{OH}-]$} & $\underline{\text { ECC }}$ & $\underline{\text { Atm }}$ \\
\hline 1 & -++- & 55 & 2.5 & High & Air \\
2 & -++-+ & 55 & 2.5 & Low & $\mathrm{N}_{2}$ \\
3 & +-- & 55 & 0.5 & Low & Air \\
4 & +-++ & 55 & 0.5 & High & $\mathrm{N}_{2}$ \\
5 & -+- & 25 & 2.5 & Low & Air \\
6 & ++-+ & 25 & 2.5 & High & $\mathrm{N}_{2}$ \\
7 & +-- & 25 & 0.5 & High & Air \\
8 & +-++ & 25 & 0.5 & Low & $\mathrm{N}_{2}$ \\
9 & $000+$ & 40 & 1.5 & Mid & Air \\
10 & $000-$ & 40 & 1.5 & Mid & $\mathrm{N}_{2}$ \\
11 & & 40 & 1.5 & None & Air \\
12 & & 40 & 1.5 & None & $\mathrm{N}_{2}$
\end{tabular}

Notes: 1. KTPB solids present at $4 \mathrm{wt} \%$ concentration.

2. ECC concentrations represent ratios of High $=2.0 \mathrm{X}, \mathrm{Mid}=1.0 \mathrm{x}$, and Low $=0.5 \mathrm{x}$.

3. Temperature in units of ${ }^{\circ} \mathrm{C}$.

4. Hydroxide Ion concentration in units of $\mathrm{M}$.

5. Tests numbered 11 and 12 are control samples, not part of the statistical design. 
The experiments occurred at constant temperature. Personnel monitored the temperatures within the air space of the ovens to $\pm 2{ }^{\circ} \mathrm{C}$ using thermometers traceable to NIST standards.

Temperatures were monitored by laboratory and operations personnel at least once per shift.

The laboratory notebook, WSRC-NB-97-61, contains data collected in this investigation. Furthermore, data collected and procedures used in this study met requirements defined in the Task Technical Plan ${ }^{11}$ and Task Quality Assurance Plan. ${ }^{12}$

Table 3. Enhanced Comprehensive Catalyst

Soluble Metal Additives

$\mathrm{Cu} \quad 1.7 \mathrm{mg} / \mathrm{L}$

$\mathrm{Ru} \quad 0.8 \mathrm{mg} / \mathrm{L}$

$\mathrm{Rh} \quad 0.2 \mathrm{mg} / \mathrm{L}$

$\mathrm{Pd} \quad 0.4 \mathrm{mg} / \mathrm{L}$

$\mathrm{Ag} \quad 0.6 \mathrm{mg} / \mathrm{L}$

$\mathrm{Fe} \quad 2.6 \mathrm{mg} / \mathrm{L}$

$\mathrm{Cr} \quad 60 \mathrm{mg} / \mathrm{L}$

$\mathrm{Hg} \quad 2.2 \mathrm{mg} / \mathrm{L}$

Cd $\quad 0.4 \mathrm{mg} / \mathrm{L}$

$\mathrm{Zn} \quad 8.7 \mathrm{mg} / \mathrm{L}$

Mo $12 \mathrm{mg} / \mathrm{L}$

- $\mathrm{Ce} \quad 0.3 \mathrm{mg} / \mathrm{L}$

$\mathrm{Si} \quad 16 \mathrm{mg} / \mathrm{L}$

$\mathrm{Se} \quad 1 \mathrm{mg} / \mathrm{L}$

As $\quad 0.04 \mathrm{mg} / \mathrm{L}$

$\mathrm{Pb} \quad 1.2 \mathrm{mg} / \mathrm{L}$

Sn $\quad 2.1 \mathrm{mg} / \mathrm{L}$

Co $\quad 0.04 \mathrm{mg} / \mathrm{L}$

$\mathrm{Ca} \quad 12.2 \mathrm{mg} / \mathrm{L}$

$\mathrm{Sr} \quad 0.1 \mathrm{mg} / \mathrm{L}$

La $\quad 0.05 \mathrm{mg} / \mathrm{L}$
Solid Additives

MST 2g/L --

Sludge Solids $2 \mathrm{~g} / \mathrm{L}$

$\mathrm{Cu}$ $2 \mathrm{mg} / \mathrm{L}$

$\mathrm{Ru} \quad 4.6 \mathrm{mg} / \mathrm{L}$

$\mathrm{Rh} \quad 1.2 \mathrm{mg} / \mathrm{L}$

$\mathrm{Pd} \quad 2.2 \mathrm{mg} / \mathrm{L}$

$\mathrm{Mn} \quad 118 \mathrm{mg} / \mathrm{L}$

$\mathrm{Fe} \quad 576 \mathrm{mg} / \mathrm{L}$

$\mathrm{Cr} \quad 4 \mathrm{mg} / \mathrm{L}$

$\mathrm{Ni} \quad 50 \mathrm{mg} / \mathrm{L}$

Al $\quad 96 \mathrm{mg} / \mathrm{L}$

$\mathrm{Mg} \quad 2 \mathrm{mg} / \mathrm{L}$

$\mathrm{Zn} \quad 4 \mathrm{mg} / \mathrm{L}$

$\mathrm{Pb} \quad 6 \mathrm{mg} / \mathrm{L}$

Organic Compounds

Diphenylmercury $\quad 150 \mathrm{mg} /$

Benzene $\quad 750 \mathrm{mg} / \mathrm{L}$

\section{HPLC Analysis Difficulties}

These samples were prepared for HPLC analysis according to the Task Plan WSRC-TR-96-0364, Rev. 0. This protocol transfers $1.0 \mathrm{~mL}$ of sample by pipette into a $10 \mathrm{~mL}$ volumetric flask followed by the addition of $2.5 \mathrm{~mL}$ of potassium phosphate buffer solution. The analyst then dilutes with acetonitrile to a final volume of $10 \mathrm{~mL}$ mark. The mixture in the volumetric flask is 
agitated for several minutes and then allowed to stand until separation between the aqueous layer and the acetonitrile layer occurs. The top acetonitrile layer is filtered through a 0.2 micron filter disk and then analyzed by HPLC.

Generally, the compounds (NaTPB, 3PB, 2PB, 1PB, Phenol and biphenyl) prove stable in acetonitrile for at least 24 hours as evidenced by subsequent analysis of the same samples the next day. However, conflicting "time zero" and other irregularities caused the researchers to repeat analysis for several of these samples. In particular, this group of samples, upon standing for a minimum of one hour in acetonitrile, began to noticeably decompose when examined by HPLC. To correct this problem, analysts injected samples onto the HPLC column within $0.5 \mathrm{~h}$ of preparation (i.e., before significant decomposition could occur).

\section{Experimental Results}

The experiments examined the decomposition of triphenylborane using a statistical design. Tables 4 through 7 and Figures 1 through 4 of Attachment 1 gives the HPLC results for each of the tests performed.

Personnel analyzed the concentrations of the triphenylborane as a function of time to derive pseudo-first order rate constants and determine the confidence of the effect of variables on the rate of decomposition using the Microsoft $^{\circledR}$ Excel data regression function.

\section{Effect of Atmosphere}

Previous testing does not provide a clear understanding of the effect of atmosphere in the decomposition of triphenylborane. Hyder ${ }^{7}$ showed that oxygen content in the salt solution had a significant affect on the rate of decomposition of the phenylborates. Triphenylborane was examined in three tests. In two of the tests, oxygen was not observed in the solution. These tests showed more decomposition of triphenylborane than the single test which contained oxygen in the solution. Crawford and Peterson ${ }^{8}$ followed with a set of tests under inerted conditions and observed a lower rate of triphenylborane decomposition.

These tests indicate that atmosphere can play a significant role. Tests prepared under a nitrogen atmosphere showed higher pseudo-first order rate constants than samples prepared under air as shown in Table 7 of Attachment 1. The current tests with inerted samples made every effort to maintain the slurry purged with nitrogen along with the headspace of the reaction vessel. Sparging of solutions used in preparing the simulant helped ensure lower concentrations of oxygen in the solutions for the current study. Also, the design of the reaction vessel precluded leaks much better than the equipment used by Crawford. ${ }^{8}$

Comparing the data from test series T5-B1 and T5-C1, as shown in Table 6 of Attachment 1, provides evidence of the role of oxygen. Both series had low levels of catalyst held at $55^{\circ} \mathrm{C}$. 
Test series T5-B1 and test series $\mathrm{T} 5-\mathrm{C} 1$ occurred in nitrogen and air, respectively. Test series T5-B1 decomposed readily from $1947 \mathrm{mg} / \mathrm{L}$ to $65 \mathrm{mg} / \mathrm{L}$ after 68 hours; whereas, test series T5$\mathrm{Cl}$ decomposed from $1715 \mathrm{mg} / \mathrm{L}$ to only $1200 \mathrm{mg} / \mathrm{L}$. This represents a reduction in the pseudofirst order rate constants from $0.050 \mathrm{~h}^{-1}$ to $0.0053 \mathrm{~h}^{-1}$ for series T5-B1 and T5-C1, respectively.

The four test series design as the mid-point to the statistically-designed matrix should show the same effect of atmosphere. These test series include T5-Q and T5-R (of Table 7) along with T5$\mathrm{E} 1$ and T5-F1 (of Table 6) with the former inerted and the latter in air in each series. Comparing test series T5-Q and T5-R shows in a 73 hour period that the air-sealed T5-Q series is slightly more reactive. The T5-Q tests lost $423 \mathrm{mg} / \mathrm{L}$ of triphenylborane; whereas, the T5-R series lost $311 \mathrm{mg} / \mathrm{L}$ of triphenylborane. Comparing the T5-E1 and T5-F1 test series, the nitrogen-inerted T5-F1 series showed more reaction in which a loss of $407 \mathrm{mg} / \mathrm{L}$ versus $358 \mathrm{mg} / \mathrm{L}$ for T5-E1. However, due to the slower rate of reaction at $40^{\circ} \mathrm{C}$ and the problems associated with the analysis of the first set of experiments (as described in the Experimental Section), the data does not confirm the effect of atmosphere on the decomposition of triphenylborane.

\section{Effect of Catalyst Concentration}

The effect of catalyst differs for the samples prepared in air or nitrogen. In air atmosphere, the decomposition rate varies with catalyst concentration to the power of $1.5 \pm 0.7$. Comparing the T5-A1 and T5-C1 data from Table 6 gives this value. The T5-A1 test in air used a high level of catalyst; whereas, the T5-C1 test, also in air, had a low level of catalyst. The triphenylborane quickly decomposed in the Al series from $1745 \mathrm{mg} / \mathrm{L}$ to $10 \mathrm{mg} / \mathrm{L}$ in 26.5 hours. Triphenylborane in the T5-C1 series test decomposed more slowly from $1715 \mathrm{mg} / \mathrm{L}$ to only 1200 $\mathrm{mg} / \mathrm{L}$ after $68^{-}$hours.

The regressed data, however, does not show a catalyst concentration dependency in the inerted tests. This indicates sufficient catalyst at the $0.5 \times$ level under inert conditions in the presence of tetraphenylborate solids. Examining the data from test series T5-B1 and T5-D1 shows this behavior. Test T5-B1 contained a low level of catalyst, while test T5-D1 had a high level of catalyst. There does not appear to be any difference to the rate of decomposition for the two experiments. Both tests lost approximately $1500-1700 \mathrm{mg} / \mathrm{L}$ in the course of 44.5 hours.

\section{Effect of Hydroxide Ion Concentration}

We anticipated an increase in the decomposition rate for triphenylborane at higher hydroxide concentration. This effect is not evident by examination of the data. If one compares the decomposition data of test series T5-N and T5-P, the hydroxide ion concentration is $2.5 \mathrm{M}$ and $0.5 \mathrm{M}$, respectively. Both samples were sealed under nitrogen and were conducted at $55^{\circ} \mathrm{C}$, and, as stated above, the catalyst concentration difference can be neglected. The pseudo-first order 
rate constants derived from the data are $0.06 \mathrm{~h}^{-1}$ for test series T5-N and $0.07 \mathrm{~h}^{-1}$ for test series T5-P. Likewise, the rate constants derived from the similar test series T5-U and test series T5-X at $25^{\circ} \mathrm{C}$ are $0.003 \mathrm{~h}^{-1}$ and $0.002 \mathrm{~h}^{-1}$, respectively.

\section{Temperature Dependence}

Table 8 contains pseudo-first order rate constants for the air and nitrogen systems derived from the regressed data. The regression gave activation energies of $59.88 \pm 27.73 \mathrm{~kJ} / \mathrm{mol}$ and $99.11 \pm$ $20.14 \mathrm{~kJ} / \mathrm{mol}$ for the air and nitrogen systems, respectively. Figure 5 plots this temperature dependence. Also, Figure 1 includes, for comparison, data previously obtained by Crawford in tetraphenylborate slurries ${ }^{9}$ and copper catalyzed ${ }^{8}$ reactions along with the data from Hyder's ${ }^{7}$ filtrate testing.

The rate constants derived from the data of the nitrogen system provide higher values than the constants from the air system. The data suggests that the slurry of Crawford's study became anoxic. Extrapolation of Crawford's data to lower temperatures shows a faster decomposition at $25^{\circ} \mathrm{C}$ than observed by experiment. The data from the air and inerted experiments indicate that systems with ECC and tetraphenylborate solids prove more reactive than copper-solids or copper-filtrate systems. Additionally, the air system and the inerted system in the current tests bound the Tank $48 \mathrm{H}$ data.

\section{Effect of Tetraphenylborate Solid}

Previous work ${ }^{13}$ showed the presence of potassium tetraphenylborate or sodium tetraphenylborate solid can increase the rate of decomposition of soluble sodium tetraphenylborate. Scant data exists that examines the role of the solids in the decomposition of triphenylborane; however, the highest rate of decomposition of triphenylborane occurred in a sodium/potassium tetraphenylborate slurry. ${ }^{9}$ Work by other researchers ${ }^{8}$ in exploring the decomposition of triphenylborane in the absence of solid tetraphenylborate exhibited lower rates. This study indicated a rapid decomposition of triphenylborane in a $4 \mathrm{wt} \%$ slurry. Hence, the combined data suggests that the presence of precipitate allows decomposition of triphenylborane to accelerate as observed for tetraphenylborate. 
Table 8. Pseudo-First Order Rate Constants $\left(\mathrm{h}^{-1}\right)$ for Triphenylborane

\begin{tabular}{lll}
\hline $55^{\circ} \mathrm{C}$ & Air & Nitrogen \\
& 0.015 & 0.054 \\
$45^{\circ} \mathrm{C}$ & 0.0077 & 0.017 \\
& & \\
$25^{\circ} \mathrm{C}$ & 0.0017 & 0.0014 \\
\hline
\end{tabular}

3PB Rate Constants

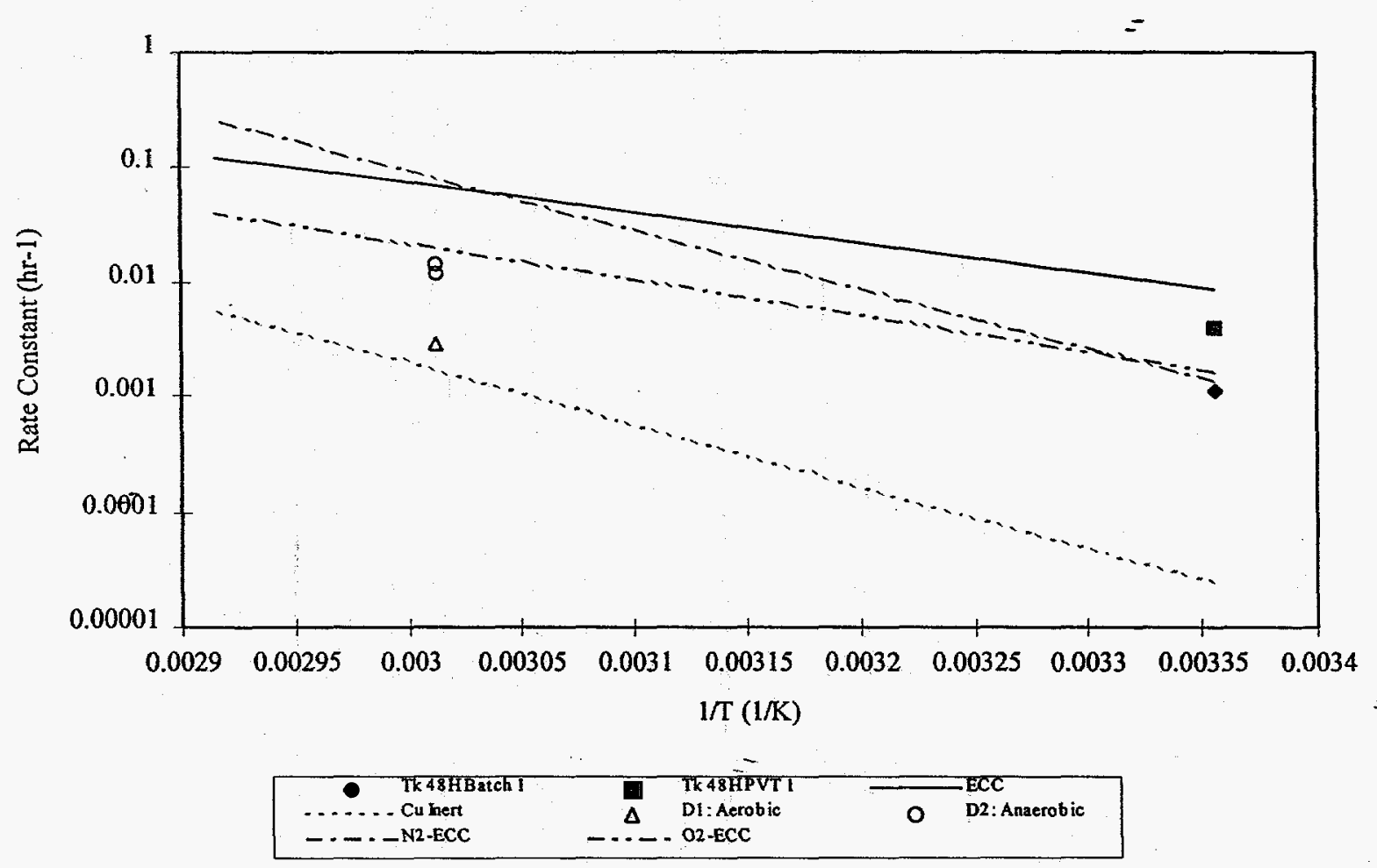

Figure 5. Triphenylborane Decomposition

ECC data are taken from reference 9.

$\mathrm{Cu}$ Inert data are taken from reference 8.

$\mathrm{N} 2-$ and $\mathrm{O} 2-\mathrm{ECC}$ data are from this report.

D1:Aerobic and D2:Anaerobic data are taken from reference 7. 


\section{Conclusions}

This work studied the decomposition of triphenylborane in a statistically-designed set of tests to determine the effects of four process variables: temperature, hydroxide concentration, catalyst concentration, and atmosphere. The results show two of the process variables are significant: temperature and atmosphere. The catalyst concentration only exhibits a statistically significant influence for triphenylborane decomposition in the presence of air.

The rate constants for the decomposition of triphenylborane in an inerted system exceed those for slurries in air but also show a higher activation energy. In the presence of air, the data suggests a lower activation energy with the rate constants at $25^{\circ} \mathrm{C}$ overlapping the inerted system values. The actual role of oxygen in this system is not completely understood. For either system, the observed rate constants bound values estimated from Batch 1 in Tank 48H, but not PVT-1, and exceed values for copper catalysis or ECC catalysis in filtrates by approximately one order of magnitude.

\section{References}

1. A. L. Watkins, "DNFSB Recommendation 96-1 Implementation Plan," DOE-SR Memorandum to S. P. Cowan, October 21, 1996.

2. D. D. Walker, M. J. Barnes, C. L. Crawford, R. F. Swingle, R. A. Peterson, M. S. Hay, and S. D. Fink, "Decomposition of Tetraphenylborate in Tank 48H (U)," WSRC-TR-96-0113, rev 0, May $10,1-997$.

3. D. D. Walker, M. L. Hyder, M. J. Barnes, and R. A. Peterson, "Intermediate Decomposition rates," SRP-IWP-97-0021, February 26, 1997.

4. W. R. Wilmarth, "Solubility of Tetraphenylborate Intermediates," WSRC-RP-97-0094, April 4, 1997.

5. J. E. Marra and J. T. Carter, "Soluble TPB Decomposition and Catalysis," HLE-TTR-97008, Rev. 0, November 14, 1996.

6. C. L. Crawford and R. A. Peterson, "Decomposition Studies of Triphenylboron, Diphenylborinic Acid, and Phenylboric Acid in Aqueous Alkaline Solutions Containing Copper," WSRC-TR-97-0045, Rev. 0, February 11, 1997.

7. M. L. Hyder, "The Role of Oxygen in the Copper-Catalyzed Decomposition of Phenyl Borates in Aqueous Solutions, "WSRC-TR-97-0046, March 17, 1997. 
8. C. L. Crawford and R. A. Peterson, “ Decomposition Studies of Triphenylborane, Diphenylborinic Acid, and Phenylboronic Acid in Aqueous Alkaline Solutions containing Potential Catalysts (U)," WSRC-TR-97-0225, Rev. 0, July'22, 1997.

9. C. L. Crawford, "Decomposition Studies of Tetraphenylborate Slurries," WSRC-TR-970046, Rev. 0, May 6, 1997.

10. "High Performance Liquid Chromatograph Operating Procedure," Manual L16.1, Procedure ADS-2655, Rev. 2, November 10, 1996.

11. W. R. Wilmarth and C. L Crawford, "Task Technical Plan for the Additional Decomposition Studies of Triphenylborane, Diphenylborinic Acid, and Phenylboronic Acid in Aqueous Solutions containing the Enhanced Comprehensive Catalyst (U)," WSRC-RP-97-293, June 5, 1997.

12. W. R. Wilmarth and C. L Crawford, "Task Quality Assurance Plan for the Additional Decomposition Studies of Triphenylborane, Diphenylborinic Acid, and Phenylboronic Acid in Aqueous Solutions containing the Enhanced Comprehensive Catalyst (U)," WSRC-RP-97294, June 5, 1997.

13. M. J. Barnes, "Sodium Tetraphenylborate Catalyst Identification: Preliminary Studies Set 2," WSRC-TR-97-0144, Rev. 0, May 28, 1997. 
Attachment 1. Analytical Results from ECC-Catalyzed Decomposition of Triphenylborane.

Table 4. Analytical Results from the $55^{\circ} \mathrm{C}$ Tests ',

\begin{tabular}{|c|c|c|c|c|c|c|c|c|c|}
\hline Sample & Reaction Time (h) & $3 P B(m g / L)$ & $2 \mathrm{~PB}(\mathrm{mg} / \mathrm{L})$ & $1 P B(m g / L)$ & Phenol (mg/L) & Temp $\left({ }^{\circ} \mathrm{C}\right)$ & {$[\mathrm{OH}]$} & Atm & [Catalyst] \\
\hline T5-M-0 & 0 & 1458 & 193 & 151 & 453 & 55 & 2.5 & Air & High \\
\hline$T 5-M-1$ & 64.5 & 10 & 25 & 551 & 488 & 55 & 2.5 & Air & High \\
\hline$T 5-M-2$ & 95.5 & 10 & 12 & 417 & 518 & 55 & 2.5 & Air & High \\
\hline$T 5-N-0$ & 0 & 1340 & 159 & 126 & 410 & 55 & 2.5 & $\mathrm{~N}_{2}$ & Low \\
\hline$T 5-N-1$ & 64.5 & 32 & 469 & 510 & 453 & 55 & 2.5 & $\mathrm{~N}_{2}$ & Low \\
\hline $\mathrm{T} 5-\mathrm{N}-2$ & 95.5 & 10 & 320 & 598 & 463 & 55 & 2.5 & $\mathrm{~N}_{2}$ & Low \\
\hline T5-O-0 & 0 & 1325 & 259 & 176 & 460 & 55 & 0.5 & Air & Low \\
\hline T5-O-1 & 64.5 & 480 & 284 & 473 & 483 & 55 & 0.5 & Air & Low \\
\hline T5-O-2 & 95.5 & 368 & 260 & 454 & 528 & 55 & 0.5 & Air & Low \\
\hline T5-O-3 & 137.5 & 241 & 221 & 452 & 583 & 55 & 0.5 & Air & Low \\
\hline T5-P-O & 0 & 1049 & 383 & 262 & 517 & 55 & 0.5 & $\mathrm{~N}_{2}$ & High \\
\hline T5-P-1 & 64.5 & 10 & 34 & 784 & 432 & 55 & 0.5 & $\mathrm{~N}_{2}$ & High \\
\hline T5-P-2 & 95.5 & 10 & 34 & 730 & 437 & 55 & 0.5 & $\mathrm{~N}_{2}$ & High \\
\hline
\end{tabular}


Table 5. Analytical Results from the $25^{\circ} \mathrm{C}$ Tests

\begin{tabular}{lccccccccc}
\hline Sample & Reaction Time $(\mathrm{h})$ & $3 \mathrm{~PB}(\mathrm{mg} / \mathrm{L})$ & $2 \mathrm{~PB}(\mathrm{mg} / \mathrm{L})$ & $1 \mathrm{~PB}(\mathrm{mg} / \mathrm{L})$ & Phenol $(\mathrm{mg} / \mathrm{L})$ & $\mathrm{Temp}\left({ }^{\circ} \mathrm{C}\right)$ & {$[\mathrm{OH}]$} & Atm & [Catalyst] \\
T5-U-0 & 0 & 1416 & 161 & 133 & 409 & 25 & 2.5 & Air & Low \\
T5-U-1 & 64.5 & 1379 & 183 & 130 & 413 & 25 & 2.5 & Air & Low \\
T5-U-2 & 95.5 & 1312 & 188 & 128 & 394 & 25 & 2.5 & Air & Low \\
T5-U-3 & 137.5 & 1162 & 216 & 149 & 377 & 25 & 2.5 & Air & Low \\
T5-V-0 & 0 & 1241 & 176 & 149 & 409 & 25 & 2.5 & $\mathrm{~N}_{2}$ & High \\
T5-V-1 & 64.5 & 1128 & 213 & 139 & 397 & 25 & 2.5 & $\mathrm{~N}_{2}$ & High \\
T5-V-3 & 137.5 & 834 & 281 & 170 & 429 & 25 & 2.5 & $\mathrm{~N}_{2}$ & High \\
T5-W-1 & 64.5 & 949 & 391 & 205 & 445 & 25 & 0.5 & Air & High \\
T5-W-2 & 95.5 & 923 & 357 & 225 & 444 & 25 & 0.5 & Air & High \\
T5-W-3 & 137.5 & 439 & 589 & 305 & 549 & 25 & 0.5 & Air & High \\
T5-X-0 & 0 & 1327 & 226 & 166 & 453 & 25 & 0.5 & $\mathrm{~N}_{2}$ & Low \\
T5-X-1 & 64.5 & 1216 & 259 & 173 & 425 & 25 & 0.5 & $\mathrm{~N}_{2}$ & Low \\
T5-X-3 & 137.5 & 1068 & 271 & 184 & 440 & 25 & 0.5 & $\mathrm{~N}_{2}$ & Low \\
& & & & & & & & & \\
\end{tabular}


Table 6. Analytical Results from the $40^{\circ} \mathrm{C}$ Tests

\begin{tabular}{lccccccccc}
\hline Sample & Reaction Time $(\mathrm{h})$ & $3 \mathrm{~PB}(\mathrm{mg} / \mathrm{L})$ & $2 \mathrm{~PB}(\mathrm{mg} / \mathrm{L})$ & $1 \mathrm{~PB}(\mathrm{mg} / \mathrm{L})$ & Phenol $(\mathrm{mg} / \mathrm{L})$ & Temp $\left({ }^{\circ} \mathrm{C}\right)$ & {$[\mathrm{OH}]$} & Atm & [Catalyst] \\
T5-Q-1 & 64.5 & 1048 & 303 & 237 & 447 & 40 & 1.5 & Air & Mid \\
T5-Q-2 & 95.5 & 893 & 338 & 219 & 478 & 40 & 1.5 & Air & Mid \\
T5-Q-3 & 137.5 & 625 & 351 & 269 & 476 & 40 & 1.5 & Air & Mid \\
T5-R-1 & 64.5 & 405 & 258 & 500 & 450 & 40 & 1.5 & $\mathrm{~N}_{2}$ & Mid \\
T5-R-2 & 95.5 & 322 & 269 & 554 & 455 & 40 & 1.5 & $\mathrm{~N}_{2}$ & Mid \\
T5-R-3 & 137.5 & 94 & 264 & 587 & 459 & 40 & 1.5 & $\mathrm{~N}_{2}$ & Mid \\
T5-S-0 & 0 & 1525 & 184 & 119 & 382 & 40 & 1.5 & Air & None \\
T5-S-1 & 64.5 & 1498 & 184 & 124 & 374 & 40 & 1.5 & Air & None \\
T5-S-2 & 95.5 & 1576 & 221 & 128 & 402 & 40 & 1.5 & Air & None \\
T5-S-3 & 137.5 & 1381 & 138 & 104 & 388 & 40 & 1.5 & Air & None \\
T5-T-0 & 0 & 1410 & 172 & 128 & 364 & 40 & 1.5 & Air & None \\
T5-T-2 & 95.5 & 1648 & 199 & 132 & 397 & 40 & 1.5 & Air & None \\
T5-T-3 & 137.5 & 1442 & 143 & 111 & 370 & 40 & 1.5 & Air & None \\
T5-STD-1 & 64.5 & 1502 & 168 & 130 & 396 & 40 & 1.5 & Air & None \\
T5-STd-3 & 137.5 & 1581 & 39 & 27 & 78 & 40 & 1.5 & Air & None \\
& & & & & & & & & \\
\hline
\end{tabular}

Note: T5-STD-1 and -3 are standards used for quality control. 
Table 6. Analytical Results from Additional Tests at $55^{\circ} \mathrm{C}$

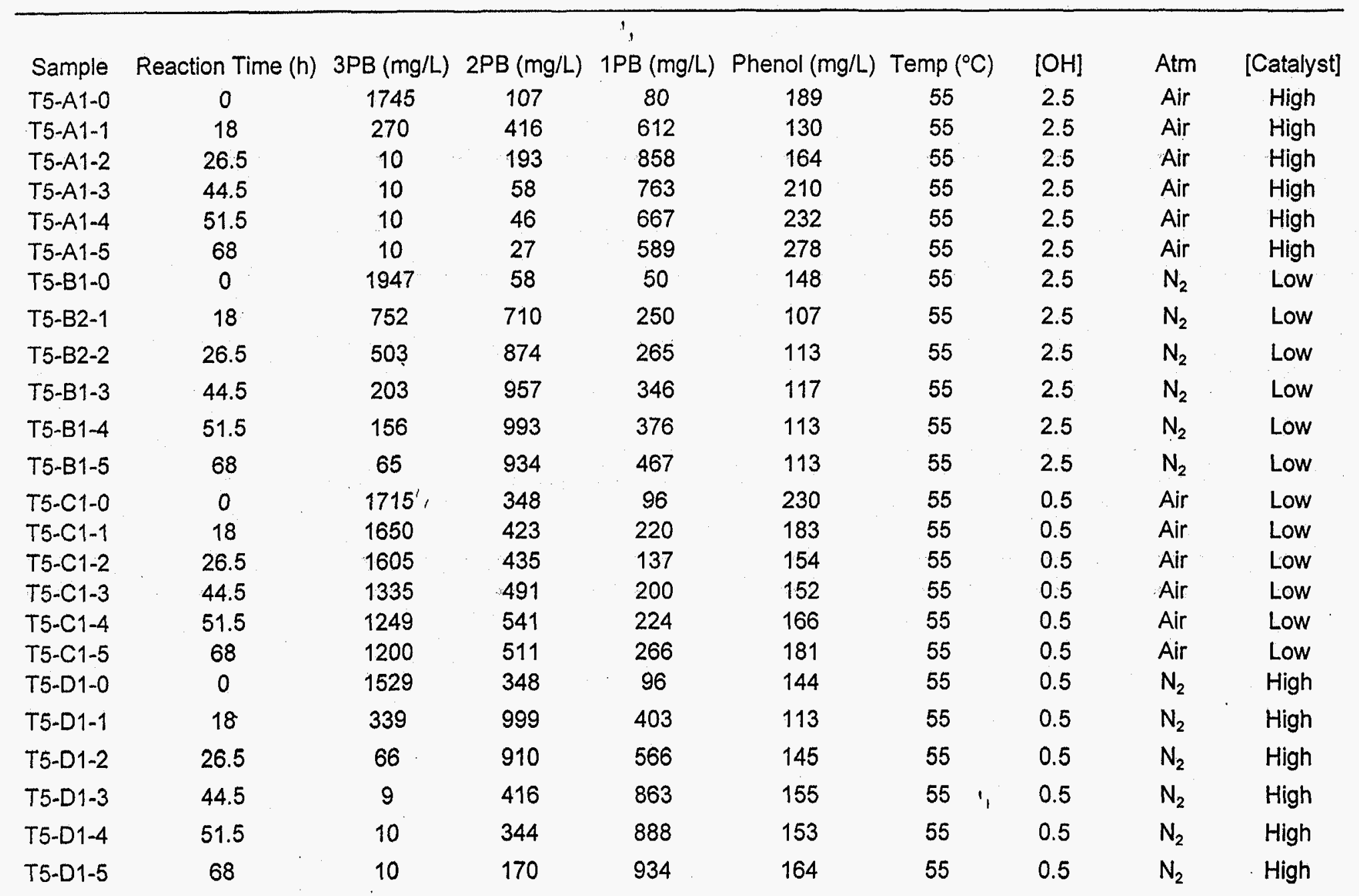


Table 7. Analytical Results from Additional Tests at $40^{\circ} \mathrm{C}$

\begin{tabular}{|c|c|c|c|c|c|c|c|c|c|}
\hline Sample & Reaction Time (h) & $3 P B(\mathrm{mg} / \mathrm{L})$ & $2 \mathrm{~PB}(\mathrm{mg} / \mathrm{L})$ & $1 P B(m g / L)$ & Phenol (mg/L) & Temp $\left({ }^{\circ} \mathrm{C}\right)$ & {$[\mathrm{OH}]$} & Atm & [Catalyst] \\
\hline T5-E1-0 & 0 & 1692 & 117 & 70 & 195 & 40 & 1.5 & Air & Mid \\
\hline T5-E1-1 & 18 & 1677 & 202 & 103 & 133 & 40 & 1.5 & Air & Mid \\
\hline T5-E1-2 & 26.5 & 1746 & 203 & 76 & 125 & 40 & 1.5 & Air & Mid \\
\hline T5-E1-3 & 44.5 & 1548 & 320 & 104 & 188 & 40 & 1.5 & Air & Mid \\
\hline T5-E1-4 & 51.5 & 1387 & 358 & 115 & 143 & 40 & 1.5 & Air & Mid \\
\hline T5-E1-5 & 68 & 1334 & 400 & 127 & 146 & 40 & 1.5 & Air & Mid \\
\hline T5-F1-0 & 0 & 1813 & 123 & 123 & 141 & 40 & 1.5 & $\mathrm{~N}_{2}$ & Mid \\
\hline T5-F1-1 & 18 & 1591 & 251 & 124 & 166 & 40 & 1.5 & $\mathrm{~N}_{2}$ & Mid \\
\hline T5-F1-2 & 26.5 & 1534 & 280 & 98 & 144 & 40 & 1.5 & $N_{2}$ & Mid \\
\hline T5-F1-3 & 44.5 & 1614 & 299 & 89 & 83 & 40 & 1.5 & $\mathrm{~N}_{2}$ & Mid \\
\hline T5-F1-4 & 51.5 & 1467 & 328 & 100 & 125 & 40 & 1.5 & $\mathrm{~N}_{2}$ & Mid \\
\hline T5-F1-5 & 68 & 1406 & 373 & 119 & 121 & 40 & 1.5 & $\mathrm{~N}_{2}$ & Mid \\
\hline
\end{tabular}




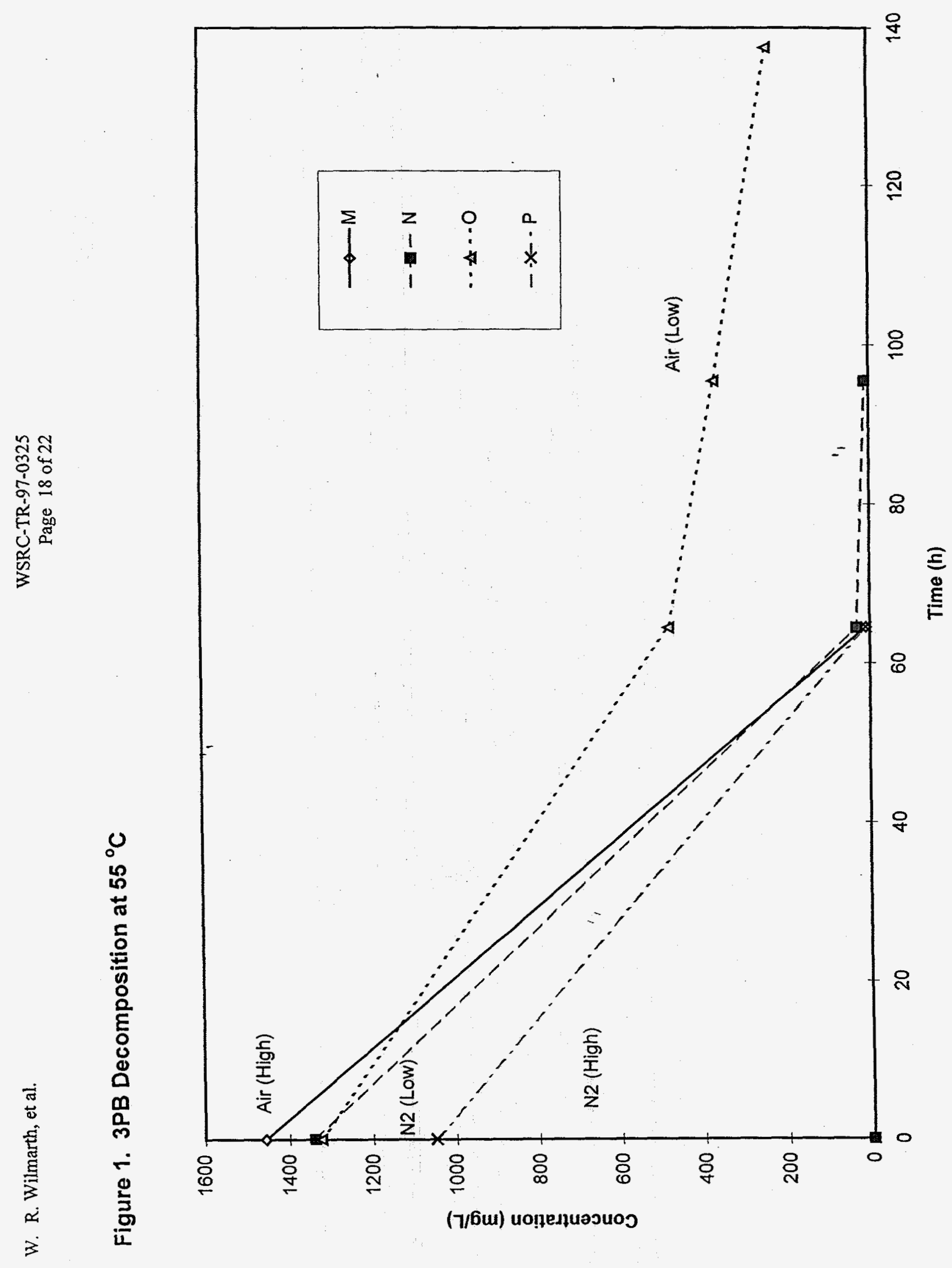




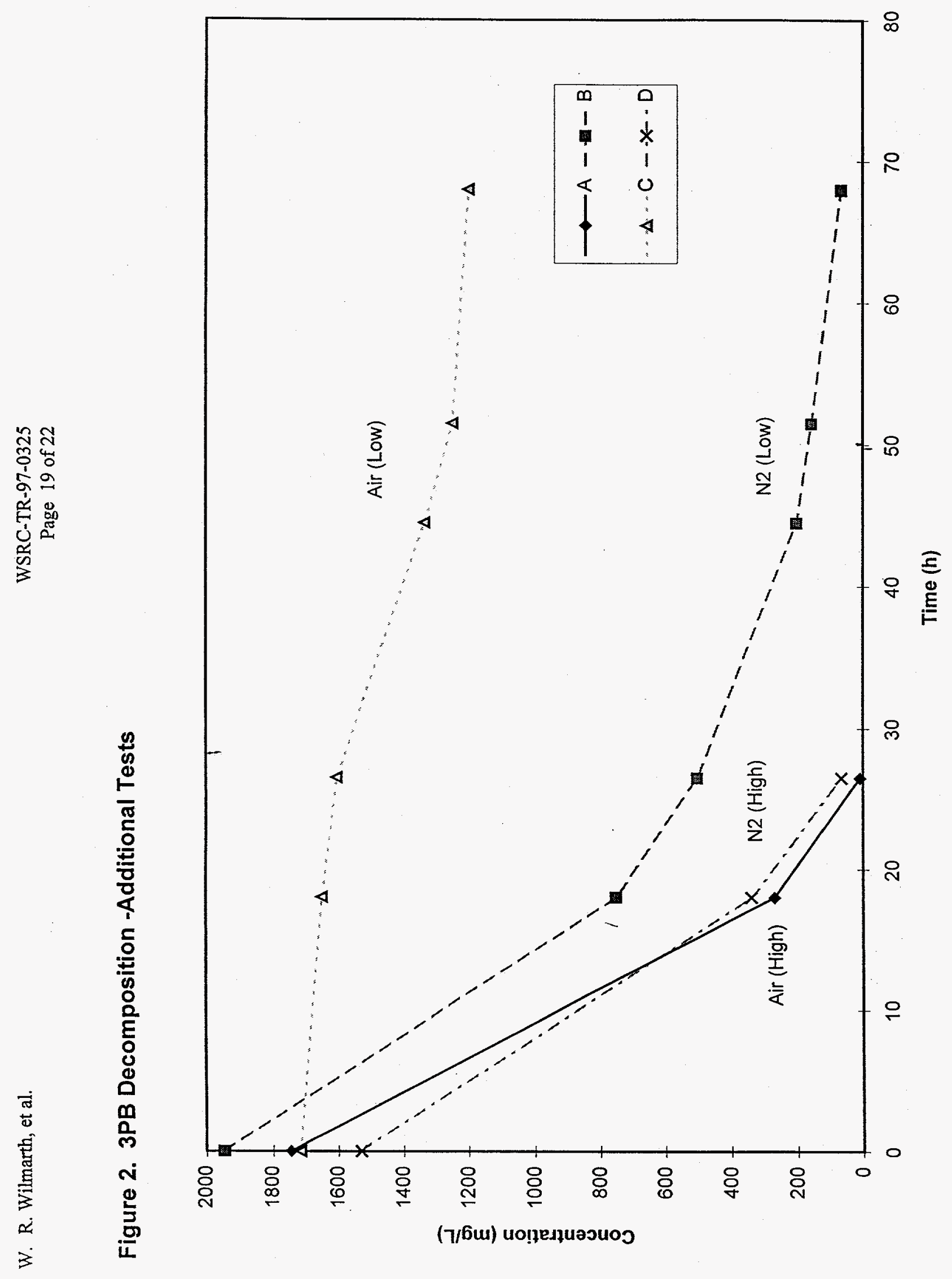




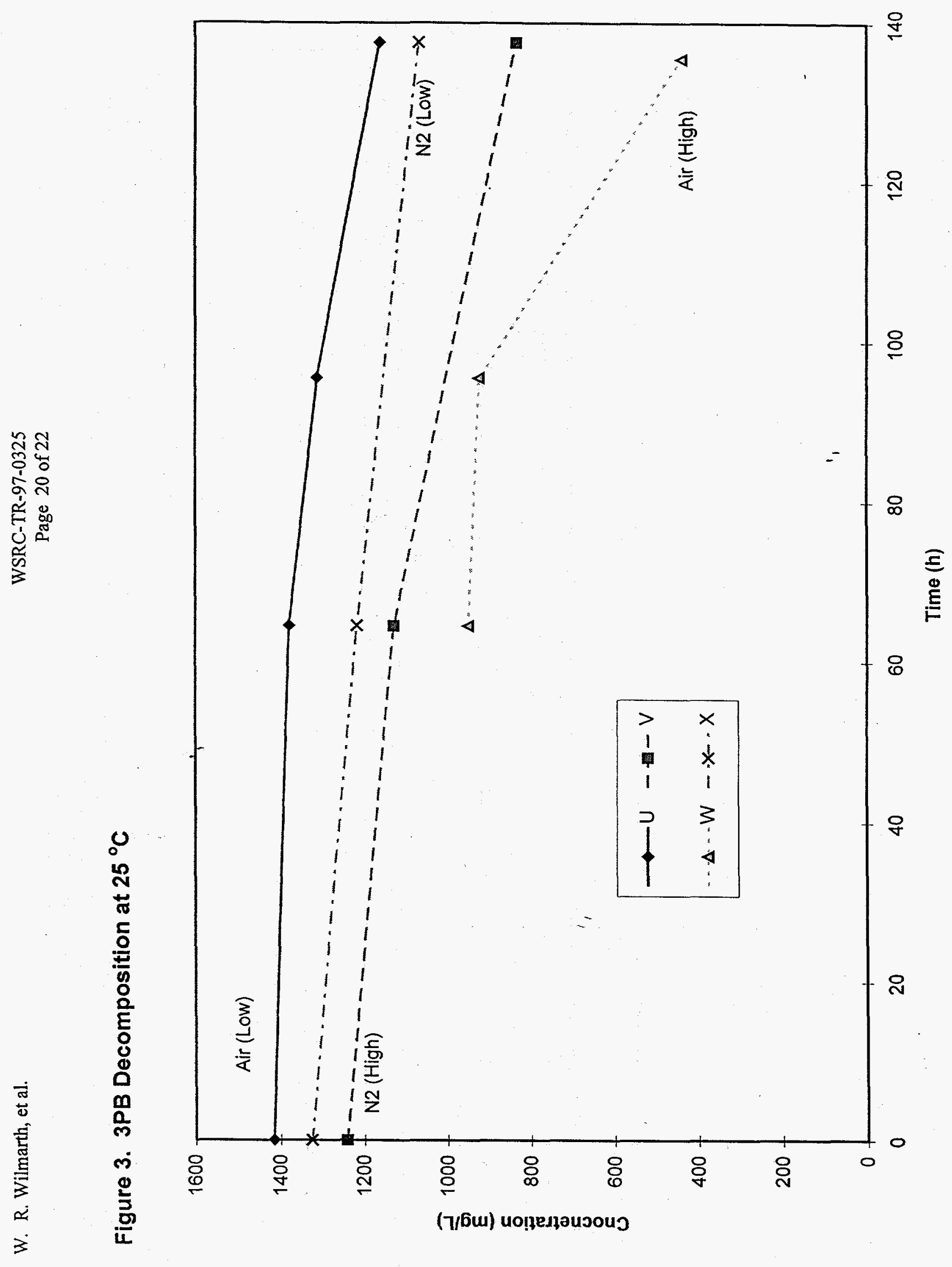




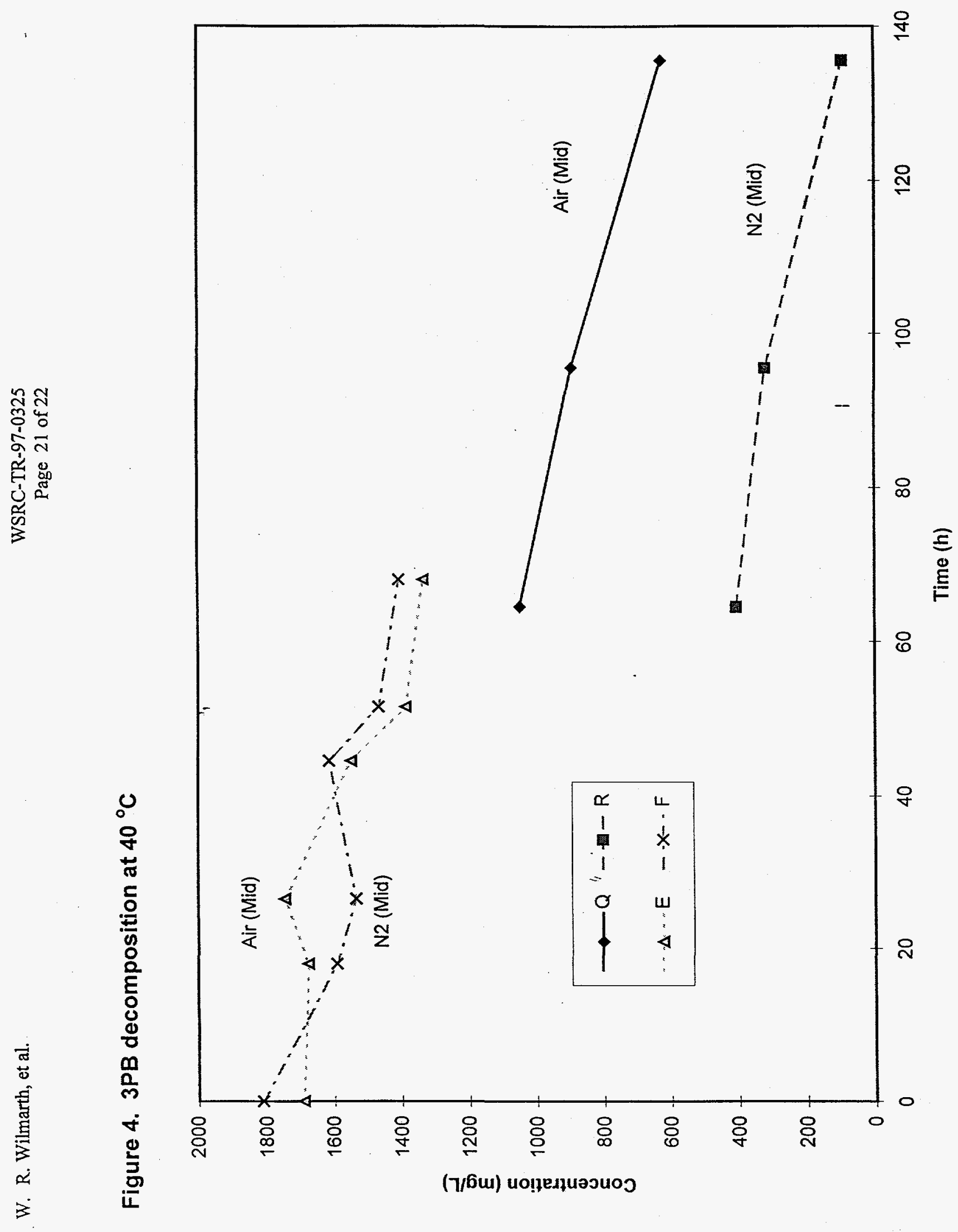


Approvals

Authors:

$10-16-97$

W. R. Wilmarth, Waste Processing Technology

Date
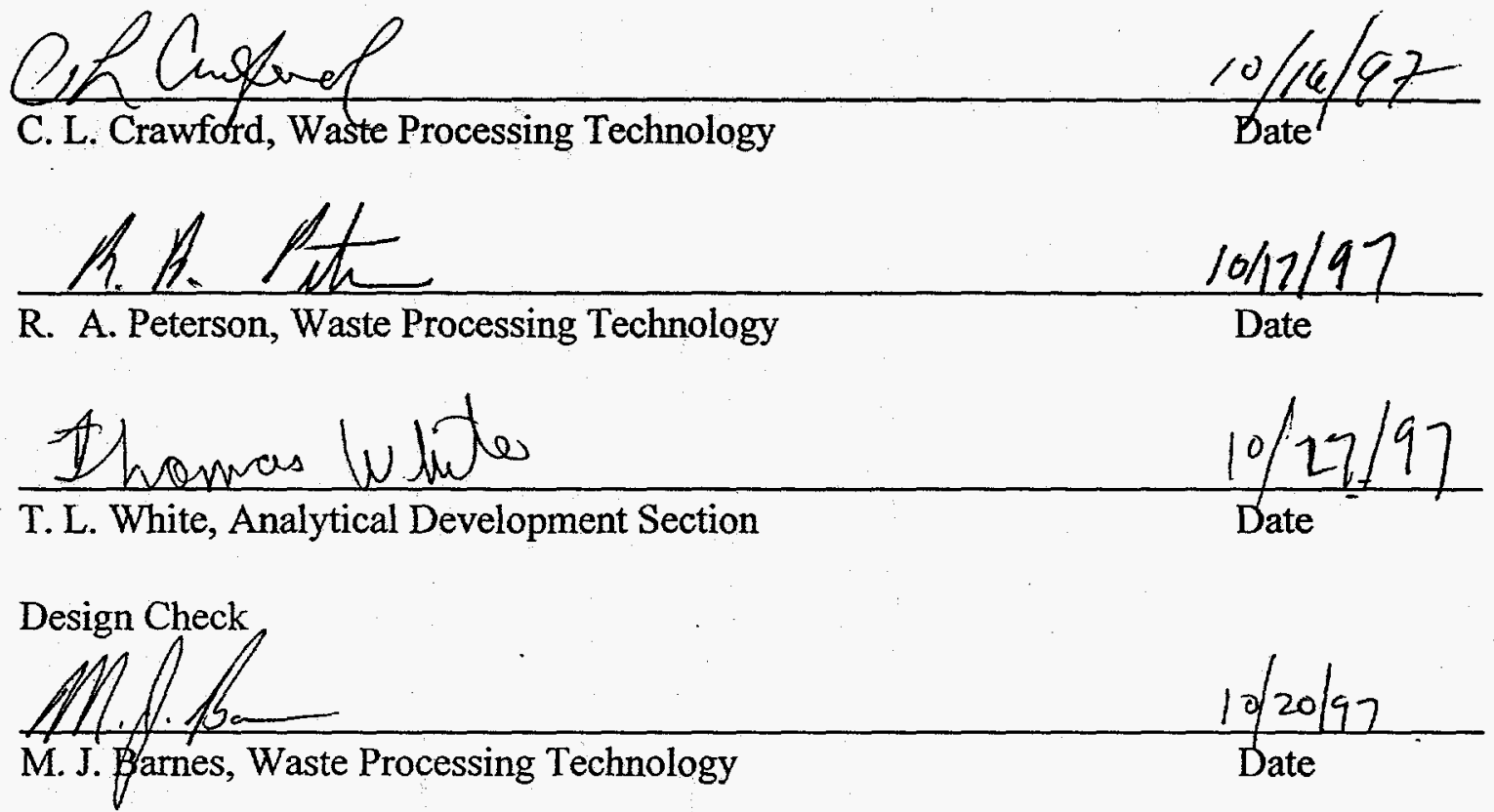

Management

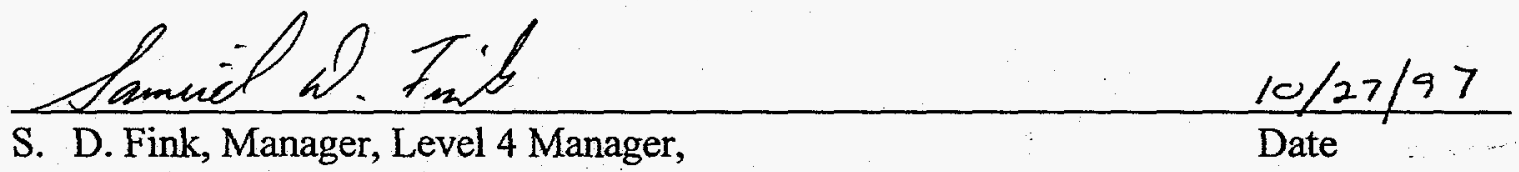

Waste Processing Technology

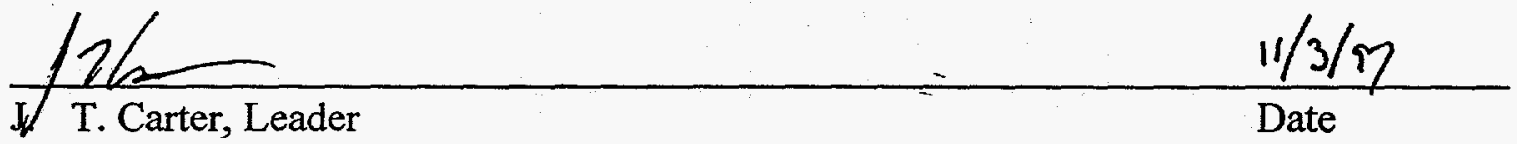

In-Tank Precipitation Flow Sheet Team

$\frac{11-4.92}{\text { Date }}$

J.L. Barnes, Deputy Manager ITP/ESP Engineering

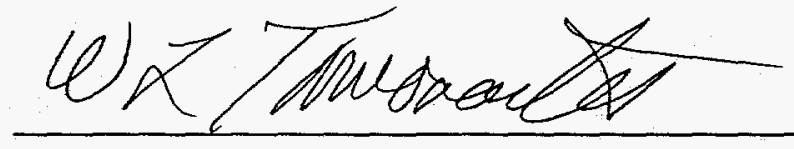

W. L. Tamosaitis, Level 3 Manager, Waste Processing Technology 


\section{DISTRIBUTION}

Amerine, D. B., 704-56H

Barnes, M. J., 773-A

Britt, T. E., 730-2B

Byrd, D., 704-56H

Carter, J. T., 704-25S

Cauthen, G. L., 241-119H

Clark, W. C., 241-119H

Crawford, C. L., 773-43A

Eberlein, S. J., 704-56H

Eibling, R., 704-T

Elder, H. H., 704-S

Fink, S. D., 773-A

Fowler, J. R., 241-121H

Griffin, J. C., 773-A

Hitchler, M. J., 730-2B

Holtzscheiter, E. W., 773-A

Hyder, M. L, 773-A

Jacobs, R. A., 704-T

Johnson, M. D., 704-56H

Keefer, M. T., 704-56H

Landon, L. F., 704-T

Lewis, B. L., 703-H

Lex, T. J., 719-4A

Marek, J. C., 704-T
McCabe, D. J., 773-43A

Menna, J. D., 241-119H

Miller, M. S., 704-56H

Montini, M. J., 704-5.6H

Morin, J. P., 719-4A

Nash, C. A., 773-A

Nelson, L. M., 773-43A

Papouchado, L. M., 773-A

Peterson, R. A., 773-A

Rutland, P. L., 241-152H

Satterfield, R. M., 719-4A

Swingle, R. F., 773-A

Tamosaitis, W. L., 773-A

Taylor, G. A., 703-H

Van Pelt, W. B., 676-1T

Walker, D. D. 773-A

Wiggins, A. W., 241-152

Wilmarth, W. R., 773-A

Wooten, A. L., 732-B

Wright, G. T., 773-A

TIM, 703-43A

HLWE File Room,File Code 1.2.5.1, 703-H

LWP Files, c/o A. Patterson, 773-A

ITP Files/L. Sumner, 704-56H 